\title{
NUMELE DE STRĂZI ŞI INSTITUȚII DIN PERSPECTIVA DIHOTOMICĂ SACRU ȘI PROFAN. STUDIU DE CAZ: ULMENI, JUDEȚUL MARAMURES,
}

\author{
Dana Covaci \\ Liceul Teoretic „George Pop de Băsești”, România

\section{Names of streets and institutions from the perspective of the dichotomy sacred - profane. Case sudy: Ulmeni, Maramureș county}

\begin{abstract}
In this paper we aim to analyse the structure of the names given to streets in the town of Ulmeni, Maramureș county, from the perspective of the dichotomy sacred - profane. In approaching this topic we started from the fact that Ulmeni has become a town through Law 83/2004, with 7,270 citizens, according to the census from 2011.

The comparison between names of streets from the previous and current period allows us to emphasise the presence of sacred and profane names in the microhodonymic system of a place in general and in particular, for the example chosen. On the other hand, it allows us to view the authorities' and citizens' involvement in the process of naming streets, neighbourhoods and institutions.
\end{abstract}

Keywords: naming, hodonym, oikonym, toponym, onomatology.

\section{Preliminarii}

Lucrarea de față pornește de la constatarea procesului de devenire urbană a localității Ulmeni, jud. Maramureș, începând cu anul 2004, când, oficial, a ajuns oraș, și până în prezent, așa cum poate fi decriptat din denumirea străzilor. „Strada, ca exponent al spaţiului public, arată Oliviu Felecan, reprezintă un topos intermediar între cel domestic și cel instituționalizat, acesta din urmă fiind locul de desfășurare a activității sociopolitice, educaţionale, culturale, economice, al petrecerii timpului liber, al divertismentului” (2013a: 318).

Datele privitoare la numărul străzilor, denumirile lor și modul de acordare al numelor le-am cules personal din nomenclatorul străzilor, prin observații directe, discuții cu personalități locale și chestionare axate pe notarea impresiilor și poveștilor legate de anumite transformări locale promovate de administrațiile succesive din perioada la care ne referim.

\section{Premise teoretice și metodologice}

Din perspectiva propusă, sacru vs. profan, situația este, net, în favoarea profanului. Motivele sunt clare. Ulmeniul a apărut și s-a dezvoltat ca o localitate rurală, în 
care centrul de interes îl constituiau doar lăcașurile de cult. La ora actuală, în localitate există pentru cultele existente mai multe biserici: Biserica Reformată, Biserica RomanoCatolică, Biserica Penticostală „Philadelphia”, Biserica de lemn (inițial greco-catolică, cu hramul Sf. Arhangheli Mihail și Gavril), Biserica nouă (2016, ortodoxă, cu hramul Sf. Treime), Biserica Sfântul Anton de Padova (cf. Covaci 2013: 427-430) și un Paraclis, în incinta Liceului „George Pop de Băsești” (cu hramul Acoperământul Maicii Domnului și Sfântul Anton de Padova). De asemenea, există o Fundație cultural-umanitară denumită Sfântul Anton de Padua ${ }^{1}$, considerat „Sfântul minunilor”.

În prezent, niciunul dintre aceste obiective nu are denumiri derivaționale în arealul localității, cum sunt înregistrate în alte zone: Strada Bisericii (Kirchegasse), în Mediaș, sau Dealul Crucii, Calea Crucii, Piața Crucii; Piața Sf. Nicolae, strada Sf. Nicolae, strada Sf. Maria, după bisericile cu același nume, în Baia Mare (cf. Rezeanu 2014: 233-245).

\section{Situația denumirilor în perioada rurală a localității}

Documentele aflate în arhiva primăriei orașului Ulmeni, înainte de declararea acestuia oraș, arată o situație destul de avansată în privința ulițelor și a reperelor. Alături de o stradă Principală, care constituia artera principală, erau un număr relativ mare de drumuri $^{2}$ și ulițe $^{3}$, motivate prin antroponime, toponime sau diverse apelative.

Între denumirile ce conțin antroponime, acestea trimit fie la oameni bogați, cu contribuții la dezvoltarea satului, fie la persoane cunoscute prin alte trăsături: Ulicioara Șouşului ${ }^{4}$, după numele unui proprietar deținător al mai multor case, pământuri și moară; Ulița lui Clisoi ${ }^{5}$, după porecla dată unei persoane foarte grase; Uliţa Anuchii din Fund' ${ }^{6}$, Ulicioara Florii Anii Mitrului, Drumul lu Gheorghe a Uănului, Drumul Nuţului Grighii (cf. Pușcaș 1982: 29).

Din punctul de vedere al structurii sintagmatice, câteva denumiri aduc informații și de natură antroponimică. Ulița Anuchii din Fund arată că, în perioada respectivă, o persoană putea fi identificată doar printr-un supranume, în cazul nostru un toponim care arăta plasarea gospodăriei în spațiul uliței, Anuța din Fund, ceea ce însemna că acolo drumul se bloca.

Următoarele denumiri - Drumu lu Gheorghe a Uănului, Drumu Nuțului Grighii,

1 Cf. Fundația "Sfântul Anton de Padua" Ulmeni. 20 de ani de existență, Baia Mare: Editura Eurotip, 2016, p. 9.

2 Drum, drumuri, s. n. din gr. dromos, direct (cf. sicil. drom, calabr. dromu) sau prin intermendiul sl. drumu (cf. bg., sb. drum, alb. dhrom). Filiera sl. era general admisă (Miklosich, Tiktin, Conev, Sanfeld, Pușcariu) și pare posibilă, fără a fi necesară (Murnu, Diculescu, Pușcariu, Rosetti). Vocalismul din română s-ar putea explica prin forma ionică droumos (Ciorănescu 2001: 303-304).

3 Uliță, ulițe, s. f. din sl. (bg., slov., rus) ulica (Miklosich, Cihac, Conev), cf. magh. utca (Cioranescu 2001: 815).

4 Inf. Mircea Șimon Sas (n. 1954), Aurica Pușcaș (n. 1956).

5 Clisoi, poreclă a unei „persoane foarte grase, căreia îi atârna carnea pe el”. În graiul local, clisă „slănină” + suf. augmentativ -oi (inf. Ana Covaci (n. 1946), Mircea Șimon Sas).

6 E vorba de casa care bloca strada și în care trăia o persoană Anuca (inf. Aurica Pușcaș). 
Ulicioara Florii Anii Mitrului - sunt importante pentru că redau și un alt mod de identificare a persoanei, din aceeași etapă veche, când formula antroponimică nu era încă fixată. Lu Gheorghe, Nuţului, Florii sunt numele persoanelor Gheorghe, Nuţu, Flore (în forma de genitiv pe lângă substantivele drum, ulicioară), dar identificate prin raportare la prenumele părinților: a Uănului (Uănu, variantă a lui Ioan, în pronunția locală), Grighii (genitiv de la Griga, femininul de la Grig, hipocoristic al lui Grigore), Anii (genitiv de la Ana, mama lui Flore, și, la rândul ei, fiica sau soția lui Mitru, hipocoristic de la Dumitru).

Ulițele marcate printr-un toponim arată fie direcția: Drumu cătră Mânău, Drumu cătră Pod, Drumu cătră Someș, Drumu Aeroportului, Drumu Gării, Ulița spre Someș, fie localizarea în interiorul satului, după repere bine cunoscute: Ulița dintre biserici, Uliţa Temeteului, Uliţa după moară, Drumu Pietrar (pietrar (< piatră + suf. -ar) „loc pietros peste care trece drumul și de unde localnicii aduceau pietriș pentru diferite scopuri”) (cf. Pușcaș 1982: 25).

Altele fac referire la vegetație: Drumu Pomnițarilor, motivat prin prezența multor pomniţari (=duzi, sg. dud, s. m. „numele a două specii de arbori cu frunzele lobate asimetric, cu fructe mici, cărnoase, albe (Morus alba) sau negre-roșietice (Morus nigra), cu un gust dulce fad, ale căror frunze constituie hrana viermilor de mătase; agud” (DEX, s. v.).

Uliţa Rățănească este greu de încadrat într-o anume categorie, înainte de a-i stabili etimologia. După spusele informatorilor, ar putea fi un derivat de la rață, datorită „rațelor multe existente pe această uliță” sau de la numele de familie Raț. Noi credem însă că nu aceste nume pot fi etimonul corect. De la apelativul rață nu poate exista un astfel de derivat, iar din datele statistice ale primăriei Ulmeni reiese că nu existau pe această uliță familii cu numele $\operatorname{Raț}(a)$.

Având în vedere numele satelor din jurul localității, am reținut că unul se numește Sârbi, după numele populației de această etnie. Întrucât pe ulița respectivă au existat multe familii de etnie maghiară și, probabil, sârbă, ale căror nume se regăsesc și astăzi, considerăm că, la baza lui, se află apelativul rác „sârb”, de unde rom. Raţiu (Graur 1965: 83). De la acesta, cu sufixele -an și -esc/-ească, a putut rezulta rățănesc/rățănească: Ulița Rățănească.

\section{Denumirile străzilor în perioada actuală}

Potrivit cu numărul de locuitori și cu întinderea spațială a orașului, numărul de străzi este redus, abia 28 , dar suficiente pentru a putea desprinde spiritualitatea izvorâtă de trecerea la noul statut, manifestată „pe direcții și categorii axiologice și diacronice, asociate cu aspecte de natură economică, istorică, social-politică” (Rezeanu 2014: 65). „Aceasta presupune, remarcă Adrian Rezeanu, apariția și selectarea unor modele culturale, permisive în anumite etape, admise sau respinse prin ignorare, de masa cetățenilor urbani. Acest sistem de nume, constituit dintr-un amalgam de simboluri, este supus, la scară diacronică, unui proces de stratificare, uneori orală, în care apariția treptelor gradate de desuetudine a determinat o ierarhizare, care funcționează, indiferent de pozițiile administrative locale” (2014: 65). 
O primă remarcă pe care o facem este legată de dispariția așa-numitei străzi Principale și a apelativelor drum, uliță, ulicioară, prezente și aici, ca în toate satele din Ardeal.

În al doilea rând constatăm faptul că în localitate nu există un centru de iradiere a străzilor, precum în orașele vechi sau care au avut dintotdeauna statutul de oraș, ceea ce este încă un semn de transformare a unui sat în oraș. În marea lor majoritate, străzile pornesc din cea care denumește artera de circulație principală ce trece de-a lungul localității și care, de fapt, este o stradă principală. În prezent este denumită str. Petre Dulfu, după numele scriitorului născut în Tohat, astăzi cartier al orașului Ulmeni.

Raportate la aspectul motivat sau nemotivat, mai puțin evident în cazul de față, aducem următoarele precizări.

Sunt motivate străzile care se referă la:

(1) repere prezente sau cunoscute în memoria colectivă: depozite, calea ferată, loc pietros, fag, nuci, plopi, pod, salcâmi, de unde denumirile actuale, de str. Depozitelor (ulița ) ), str. Fagului, str. Pietrar ${ }^{7}$ (drumu ), str. Plopșor, str. Podului (drumu cătră pod), str. Salcâmilor, str. Trenului;

(2) vecinătăți topografice, care arată punctul spre care duce strada: balastieră, câmp, gară: str. Balastierei, str. Câmpului, str. Gării;

(3) repere care indică direcția de mers sau de ieșire din oraș: str. Codrului, str. Silvaniei, str. Someșului.

Situațiile de sub (1) sunt interesante și prin faptul că pot caracteriza o situație mai veche, când localitatea avea statutul de sat. În acea perioadă existau locuri în care se găseau salcâmi, plopi, pâlcuri de pădure, grădini cu nuci etc., care, în timp, au fost sistematizate și utilizate pentru construirea de case, pe măsură ce populația a început să crească, mai ales după perioada colectivizării. Forma de genitiv sub care apar unele nume nu are valoare posesivă, ci face trimite la reperul local, care, în unele cazuri, mai există (pod, depozite), în altele nu, fag, plopi, salcâmi, dispăruți prin modernizarea localității.

Și denumirile străzilor menționate sub (3) au importanță prin faptul că fac trimitere la un reper cunoscut, apropiat sau îndepărtat ${ }^{8}$ : Codru este ținutul știut drept Zona Codrului și care se întinde de la Ulmeni spre sud și vest ${ }^{9}$; Silvania, cu orașul Cehu Silvaniei se află în partea de est a Ulmeniului; Someșul este unul dintre râurile mari și importante ale Transilvaniei, care trece prin apropierea orașului Ulmeni.

Dintre străzile ale căror denumiri trimit la nume de personalități, unele au o motivație „rezultată dintr-un transfer denominativ extensional de la reperul dominant”

7 Grafia cu i, cum apare în Nomenclatorul primăriei, poate deruta în stabilirea etimonului, fiindcă - ar este atât un sufix care arată locul: cuibar, grohotar „un loc pietros, unde sunt îngrămădite multe pietre”, lujar „culcuș, vizuină”, frunzar etc., cât și un sufix care arată agentul, nomina agentis: albinar, brutar, ciubotar, lingurar, strungar etc.; instrumentul: culeșer, stăvilar, țântar etc.; recipientul: blidar, merindare etc.; și încă multe altele, cf. Pascu (1916: 79-93).

8 Vezi Drumul Bistriței, Suceava; Drumul Cisnădiei, Sibiu, Drumul Braşovului, Azuga etc.

9 Pentru arealul cuprins în zona Codrului, v. Covaci (op. cit.: 427-430). 
(Rezeanu 2014: 52), în cazul nostru, locul de naștere. Aici se înscriu străzile care trimit la nume de personalități locale: Dr. Florian C. Ulmeanu ${ }^{10}$ este strada care include casa în care s-a născut profesorul și omul de știință. Petre Dulfu $u^{11}$ denumește artera principală, care trece și prin Tohat, sat în care s-a născut scriitorul, astăzi cartier al orașului Ulmeni. George Pop de Băseștiti a devenit numele unui liceu din localitate și nume de stradă. Pentru toate, reperul este satul Băsești, din apropierea orașului Ulmeni, oiconim care se regăsește și în formula antroponimică a omului politic care a fost. Str. Emil Gavriș ${ }^{13}$ își are punctul de pornire în satul nașterii rapsodului popular, Chelința, localitate componentă a orașului Ulmeni. Str. Petöfi Sandor face trimitere la etnia majorității locuitorilor de pe stradă.

Facem aici precizarea că abia în 2004 a apărut această stradă, dată după numele unui poet de etnie maghiară ${ }^{14}$, deși maghiari au locuit aici încă de la atestarea localității, anul 1405 (Suciu II: 217, s. v.).

Alte străzi au denumiri nemotivate direct și urmează modelul cunoscut în majoritatea orașelor, cu excepția celor care au străzile numerotate, cum este, de exemplu orașul Tăuți Măgherăuș, tot din jud. Maramureș - str. Mihai Eminescu, str. George Coșbuc, str. Avram Iancu, str. Iuliu Maniu, str. Vasile Lucaciu, sau unul încetățenit în țara noastră după instalarea regimului comunist: str. Primăverii, str. Tineretului, str. Unirii, str. Zorilor, care au la bază cuvinte, devenite reper pentru caracterizarea noii orânduiri sociale, primăvară, tineret, unire, zori.

Din cele prezentate, deducem, în acord cu Oliviu Felecan, că „diversele finalități ale unui spațiu de tipul celui mai sus-menționat sunt anunțate (și) în numele străzilor respective, care, pe de o parte, conservă tradiția epocilor anterioare, iar, pe de altă parte, reproduc moda nominală de la un moment dat, tributară influențelor politice, administrative, sociale sau etnice” (2013a: 318).

În privința structurii numelor, există unul singur, Plopșor, din sintagma Strada Plopșor, care este derivat $(<$ plop + sufixul diminutival -ușor și apoi cu căderea lui -uaton: plop $>$ plopuşor $>$ plopşor.

10 Florian C. Ulmeanu (1903-1973, Ulmeni). Întemeietorul medicinei sportive, membru post-mortem al Academiei de Medicină din România.

11 Petre Dulfu (1856-1953, Tohat, astăzi cartier al or. Ulmeni, jud. Maramureș), scriitor român, care a scris Snoave, povești și balade populare, prelucrate în versuri (DE II 1996: 154).

12 Gheorghe Pop de Băsești (1835-1919, Băsești, jud. Maramureș), om politic român. Vicepreședinte (1881-1902) și președinte (1903-1919) al Partidului Național Român. Unul dintre inițiatorii și conducătorii mișcării memorandiste din 1892-1894. Președinte al Marii Adunări Naționale de la Alba Iulia (18 nov./ 1 dec. 1918), care a proclamat unirea Transilvaniei cu România (DE V 2004: 437).

13 Emil Gavriș (1915-1989, Chelința, jud. Maramureș), cântăreț român de muzică populară și de romanțe. Culegător de folclor, compozitor de romanțe, prelucrări corale de folclor și cântece pentru copii (DE II 1996: 415).

14 Din informațiile respondenților am aflat că numele străzii s-ar fi dat la insistențele unui consilier maghiar. 


\section{Concluzii}

Faptele prezentate confirmă aspecte importante, evidențiate, pentru alte localități, și de alți cercetători. Oliviu Felecan făcea precizarea că „naming streets cannot be understood as an autonomous process, but needs to be examined as part of a wider picture, that of language in society or, more precisely, of language in evolution in a changing society. Hodonyms are, in fact, proper names based on other proper or common names, which can be interpreted as socio-, psycho- and ethnolinguistic indices in society at a given point in time" (Felecan 2015: 230).

În faza anterioară de dezvoltare a localității existau două situații în care termenii religioși, biserică și cimitir (temeteu, în graiul local) au dezvoltat câte o extensie derivaţională: Ulița dintre Biserici și Ulița Cimitirului (Temeteului), înlocuite în perioada urbană prin str. Unirii, respectiv Petöfi Sandor, denumiri mai greu de motivat, datorită lipsei reperelor. Memoria orală a comunității știe însă că actuala denumire, numele poetului maghiar Petöfi Sandor (1823-1849) a apărut datorită faptului că pe această stradă locuiau mai multe familii maghiare ${ }^{15}$. Așa cum remarcă Oliviu Felecan, „Un critère [... ] devrait être pris en compte dans l'attribution de noms est celui de la compatibilité, de l'adéquation du signifié au signifiant, celui du nom de la rue" (2013b: 146), respectând chiar și configurația etnică a localității.

Dispariția denumirilor sacre și extensia celor profane dovedesc voința politică a administrației locale și consimțământul cetățenilor în perioada de trecerea a localității din statutul rural în cel urban, când abia începe să-și făurească o „cultură urbană” (v. Velescu 1997: 193-201).

De asemenea, apariția denumirilor mai puțin motivate, provenite de la nume de personalități sau de la alte apelative, încadrează localitatea în rândul orașelor în care cultura urbană începe să fie vizibilă.

\section{Bibliografie}

Ciorănescu, Al. 2001. Dicționarul etimologic al limbii române. București: Editura Saeculum I.O.

Covaci, D. 2013. Denumirea lăcașurilor de cult din zona Codrului. În Proceedings of the Second International Conference on Onomastics "Name and Naming". Onomastics in Contemporary Public Space, O. Felecan (ed.), 427-430. Cluj-Napoca: Mega, Argonaut.

Dicționar enciclopedic, vol. I-VI. 1993-2006. București: Editura Enciclopedică.

Felecan, O. 2013a. Hodonimie românească - între autohtonism și cosmopolitism. În Proceedings of the Second International Conference on Onomastics "Name and Naming". Onomastics in Contemporary Public Space, O. Felecan (ed.), 318-328. Cluj-Napoca: Mega, Argonaut.

Felecan, O. 2013b. Anthroponyms en odonymie (aspects théoriques). Nouvelle Revue d'Onomastique (NRO) 55: 143-151.

Felecan, O. 2015. Borders and Ethnic Identities Reflected in Street Names from Transylvanian Localities. Transylvanian Review XXIV, Supplement nr. 1/ 2015, Regionalization in Globalization: 229-244.

15 Informație primită de la Aurora Pușcaș, prof., născută în localitate (1956). 
Fundația "Sfântul Anton de Padua" Ulmeni. 20 de ani de existență. 2016. Baia Mare: Editura Eurotip.

Graur, Al. 1965. Nume de persoane. București: Editura Științifică.

Pascu, G., 1916. Sufixele românești. București, Leipzig, Viena: Librăriile SOCEC \& Co.

Primăria or. Ulmeni. Tabel nominal cuprinzând date privind denumirea străzilor, a numerelor de casă și a proprietarilor acestora, din localitatea Ulmeni. Actualizate la data de 19 aprilie 2016.

Pușcaș, A. 1982. Toponimia satelor Chelința, Mînău, Tohat, Țicău și Ulmeni (comuna Ulmeni, județul Maramureș). Lucrare de diplomă, Baia Mare, (în manuscris).

Rezeanu, A. 2014. Periplu toponimic. București: Editura Academiei Române.

Suciu, C. 1968. Dicționar istoric al localităților din Transilvania, II. București: Editura Academiei. Velescu, O. 1997. Orașul - spații culturale. Historia Urbana, tom V, nr. 2: 193-201.

Documente online (accesate în august 2017)

https://ro.wikipedia.org/wiki/ulmeni

https:www.primaria-ulmeni.ro/

ulmeni-mm.pe-harta.ro/

orasul.biz: orase din judetul maramures

ulmeni-mm.pe-harta.ro/strazi-ulmeni/maramures.html

\section{Informatori}

Ana Covaci, n. 1946

Aurica Pușcaș, prof., n. 1956

Șimon Mircea Sas, n. 1954 